\title{
Natural versus anthropogenic climate change: Swedish farmers joint construction of climate perceptions
}

\author{
Therese Asplund
}

\section{Linköping University Post Print}

\section{Tweet}

N.B.: When citing this work, cite the original article.

Original Publication:

Therese Asplund, Natural versus anthropogenic climate change: Swedish farmers joint construction of climate perceptions, 2016, Public Understanding of Science, (25), 5, 560-575. http://dx.doi.org/10.1177/0963662514559655

Copyright: SAGE Publications (UK and US)

http://www.uk.sagepub.com/home.nav

Postprint available at: Linköping University Electronic Press

http://urn.kb.se/resolve?urn=urn:nbn:se:liu:diva-130411 


\title{
Natural vs anthropogenic climate change - Swedish farmers' joint construction of climate perceptions
}

\author{
Therese Asplund ${ }^{\mathrm{a}}$ \\ ${ }^{a}$ Centre for Climate Science and Policy Research/Department of Thematic Studies - \\ Water and Environmental Studies, Linköping University, Linköping, Sweden
}

\begin{abstract}
While previous research into understandings of climate change has usually examined general public perceptions, this study offers an audience-specific departure point. This paper analyses how Swedish farmers perceive climate change and how they jointly shape their understandings. The agricultural sector is of special interest because it both contributes to and is directly affected by climate change. Through focus group discussions with Swedish farmers, this study finds that: 1) farmers relate to and understand climate change through their own experiences, and 2) climate change is understood either as a natural process subject to little or no human influence or as anthropogenic, 3) various communication tools contribute to the formation of natural and anthropogenic climate change frames. The article ends by discussing frame resonance and frame clash in public understandings of climate change, and by comparing potential similarities and differences in how various segments of the public make sense of climate change.
\end{abstract}

Keywords: climate change communication, climate perceptions, farmers, focus groups, frame analysis 


\section{Introduction}

"Human influence on the climate system is clear," states the Intergovernmental Panel on Climate Change (IPCC, 2013, p. 13). The evidence supporting the claim is more detailed and includes longer-term observations and better climate modelling than earlier assessments. In parallel, or perhaps in response to advances in the physical science basis of climate change, numerous studies treat the implications of climatic change and how society can mitigate and adapt to them (for an overview, see IPCC, 2007a,b). Hulme (2009) argues that the focus has shifted from climate change being regarded as an exclusively physical phenomenon to being a social phenomenon as well, entailing many interpretations and multidimensional frames. This shift calls for an understanding of how various audiences and segments of the public understand climate change. To bring together different audiences to work towards a common goal, Moser (2010, p. 39) claims that "different audiences require distinct frames, goals, messages and messengers." Similarly, Whitmarsh and Lorenzoni (2010) suggest that, to foster dialogue and debate and, ultimately, stimulate societal responses to climate change, research into the public understanding of climate change should consider how climate change communication can be tailored to specific audiences, i.e., how climate change is communicated and framed by diverse stakeholders and groups in diverse public discourses.

Previous research into public understanding of and engagement in climate change has segmented audiences in two main ways: according to demographic variables or according to understandings, concerns, and emotional responses regarding climate change (for an overview, see Wibeck, 2013). The present paper addresses audience segmentation in terms of its relevance to climate change, building on the IPCC's identification of the agricultural sector as particularly relevant to climate change (IPCC, 
2007b). This paper examines Swedish farmers' perceptions of climate change and how, through discussion and interaction, they construct these perceptions.

Farmers differ in many respects from the general public, for example, both in being more likely to notice subtle environmental changes (Moser, 2010) and in historically displaying great adaptability to climate variations (IPCC, 2007a). Swedish agriculture makes an interesting case of audience-specific understanding of climate change, as the benefits of climate change will likely overshadow its negative consequences for this sector (Swedish Board of Agriculture [SBA], 2007; Swedish Government Official Reports [SOU], 2007:60). For Swedish agriculture, climate change is expected to bring longer growing seasons, higher yields, and opportunities to grow new crops. Furthermore, Sweden exemplifies a country where there is frequent media reporting on climate change in both the broadcast and print media (Höijer, 2010; Olausson, 2009) and in specialized media targeting farmers (Asplund, 2011; Asplund, Hjerpe and Wibeck, 2013), implying that Swedish farmers have great access to various climaterelated news stories. This paper can be seen as answering calls for more case-specific and audience-specific research into climate communication (Moser, 2010), including larger social or cultural groupings (Whitmarsh and Lorenzoni, 2010). In order to examine Swedish farmers' perceptions of climate change, climate change is here approached as an idea rather than a physical phenomenon (Hulme, 2009). The analytical purpose is not to confirm any particular understanding of climate change but to provide in-depth insights into lay peoples' sense-making processes. Specifically, this paper builds on focus group discussions with Swedish farmers and addresses the following questions:

- How do Swedish farmers perceive climate change?

- On what "evidence” are their perceptions of climate change based?

- What communicative tools contribute to shaping these perceptions? 
The article ends by discussing the resonance and clash of climate change frames, and potential similarities and differences in how various segments of the public make sense of climate change.

\section{Public perceptions of climate change}

This overview of studies of public perceptions of climate change includes findings from both quantitative and qualitative studies, and identifies five themes in this literature: 1) consensus and conflict in climate science, 2) attribution of causes of climate change, 3) levels of concern, 4) climate change frames as filtered through existing worldviews, and 5) the importance of experience in making sense of climate change.

Published studies of the public perception of climate change have mainly been conducted in the USA and Europe, so this review is dominated by Western public perceptions of climate science and climate change. Even so, climate change is framed in many ways reflecting various levels of concern.

Consensus and conflict in climate science. When it comes to climate science, similar patterns are observed in the USA and UK. The American public believe "there is solid evidence" of higher global temperatures, but is divided as to whether scientists agree that climate change is anthropogenic (Pew, 2013). Similar trends have been found in the UK, where most respondents believe climate change is happening but disagree as to whether it has or has not yet been established as largely anthropogenic (BBC, 2010; Shuckburgh, Robison and Pidgeon, 2012).

Attribution of causes of climate change. When it comes to climate change rather than climate science, i.e., to the causes of climate change rather than whether its scientific 
foundations are established, frames of natural versus anthropogenic climate change are activated. For example, the UK public commonly believes that climate change is caused partly by natural and partly by anthropogenic processes, while just over a third believes that it is mainly or entirely anthropogenic (Poortinga, Spence, Whitmarsh, Capstick and Pidgeon, 2011; Shuckburgh et al., 2012). Similar findings have been observed regarding the American public: about half of Americans think that if global warming is happening, it is caused mostly by human activities (Leiserowitz, Maibach, Roser-Renouf, Feinberg and Rosenthal, 2014; Pew Research Center, 2013), while one in three (32\%) say they think global warming is mostly due to natural changes in the environment (Leiserowitz et al, 2014).

Levels of concern. Public perceptions of climate change in the European Union (EU), covered by the Eurobarometer (EB) surveys (2008, 2012), are oriented neither towards the degree of consensus among climate scientists nor to the linkage between natural and anthropogenic causes of climate change. Instead, a general frame of concern dominates EU public perceptions of climate change (EB, 2008, 2012). Generally, the European public regards climate change as among the world's most serious problems that call for responses from various actors, such as governments, industry, and individuals. When segmenting the US public according to levels of concern, most respondents express overall concern about the harmfulness of climate change, although not all believe it to be so harmful that it calls for precaution (Leiserowitz, Maibach, Roser- Renouf, Feinberg \& Howe, 2013; Leiserowitz et al, 2014). It can generally be said that the European public is more concerned about climate change and is more likely to see it as a collective and individual responsibility than is the US public.

Climate change frames as filtered through existing worldviews. In reviewing qualitative studies, Wolf and Moser (2011) conclude that individual understandings of climate 
change are always contextualized within broader considerations, meaning that people are not "blank slates" receiving information about climate change, but that information is always and inevitably filtered through values and worldviews (see also Leiserowitz et al., 2013; Poortinga et al., 2011; Whitmarsh, 2011). Generally, studies analysing indepth understandings of climate change are lacking, so there is little insight into the dynamics of how particular ideas are shaped. However, Weber (2010) and Weiler, Keller and Olex (2012) found that laypeople use associative thinking and personal experience when learning about climate change. Similarly, associations with melting polar ice caps, endangered polar bears, floods, and droughts are found in Swedish (Wibeck, 2014), Norwegian (Ryghaug, Sørensen and Næss, 2011), and British (Smith and Joffe, 2013) focus group discussions of how climate change is understood. Combined, such studies provide insight into the processes by which climate change is understood and the processes that underlie climate perceptions.

The importance of experience in making sense of climate change. The importance of experience for environmental and climate perceptions has been recognized more recently (Akerlof, Maibach, Fitzgerald, Cedeno and Neuman, 2013; Myers, Maibach, Roser-Renouf, Akerlof and Leiserowitz, 2012; Ryghaug and Solli, 2012; Weber, 2010). It has been suggested that personal experience of climate change is interdependent with the belief that climate change is happening (Myers et al., 2012), which heightens perceptions of climate change's local risks (Akerlof et al., 2013). Although rare, studies of this matter are based on current cognitive and social psychology theories suggesting that laypeople typically rely on associative thinking and personal experience when making sense of complex issues (Kahneman, 2011). 


\section{Frame analysis of sense-making processes}

Frame analysis is chosen as the analytical lens through which questions of Swedish farmers' perceptions of climate change and their formation are analysed. A frame may be described as "a central organising idea or story line that provides meaning to an unfolding strip of events, weaving a connection among them. The frame suggests what the controversy is about, the essence of the issue” (Gamson and Modigliani, 1994, p. 376). Framing is thus a way of organizing, interpreting, and making sense of complex reality. Lakoff (2010) argues that all our knowledge makes use of frames, and that every word is defined through the frame or frames it activates; accordingly, all thinking and talking involves "framing." This paper draws on interactional frame analysis that holds that people are conversationalists who interact in varying constellations while coconstructing the meaning of their world (Dewulf et al., 2009). Similarly, Snow and Benford (1988) suggest that framing is the active process by which individuals and collective actors arrange and make sense of events to mobilize for action (Snow and Benford, 1988). To explain why some frames are more effective in mobilizing supporters than are others, Snow and Benford (1988) suggest three tasks: identifying the problem (diagnostic framing), proposing solutions (prognostic framing), and providing rationales for action (motivational framing):

Diagnostic framing concerns diagnosing an event or aspect of social life as problematic and needing alteration. The diagnosis often involves attributing blame or causality concerning the problem's cause. Generally, consensus as to problem identification is more frequent and less problematic than is attributional consensus.

Prognostic framing concerns proposed solutions to the problem, i.e., identifying strategies, tactics, and targets. 
Motivational framing concerns rationales for engaging in action, serving as a "call to arms” (Snow and Benford, 1988, p. 202). Agreement about the diagnosis and prognosis of a problem does not automatically produce a motive for action, so rationales for action go beyond problem definitions and solutions to concern issues of motivation.

Frame analysis assumes that a situation can be named and framed in various ways, constructing multiple social realities. Frames lead us to see different things, make different interpretations, explicitly or implicitly indicating a particular problem definition, solution, and potentially action. In this paper, I draw on Snow and Benford's (1988) concepts of diagnostic and prognostic framing in analysing how Swedish farmers jointly construct their understanding of climate change, its causes and potential responses.

\section{Methods}

To analyse how climate change is framed by Swedish farmers and, in particular, how these frames are formed, I conducted focus group (FG) discussions. FGs are group discussions led by a moderator who works from a predetermined set of questions (Morgan, 1998). FGs are fundamentally a way of listening to people: as Morgan (1998, p. 9) described it, "Put simply, it is your focus, but their group.” Qualitative methods in studies of public perceptions of climate change are rare but essential to fully understand public perceptions of climate change and the processes underlying them (for an overview, see Wolf and Moser, 2011).

Unlike in other qualitative social scientific methods such as interviews, FG respondents have less time to talk about individual experiences (Morgan, 1988). I nevertheless consider the group interaction to give valuable input, particularly regarding interactional 
sense-making processes, possibly outweighing the limits in exploring individual participants. Due to the effects of group dynamics, FGs have been recognized as useful in exploring interaction between participants and especially in examining how knowledge and ideas develop and operate (Kitzinger, 1994; Wibeck, Abrandt Dahlgren and Öberg, 2007).

As type of agricultural production is a factor considered relevant to climate change mitigation and adaptation in the agricultural sector (SOU, 2007), and as climate change perception studies demonstrate that age and gender influence attitudes towards climate change (EB, 2012; McCright and Dunlap, 2011), taken together, the FGs encompassed a mix of agricultural production types, ages, and genders (see Table 1). The intention was to include as many perspectives as possible and reach theoretical saturation (Glauser and Strauss, 1967) rather than to generalize the results to a larger population - which the limited sample would not allow.

Table 1. Group format

The interview guide initially comprised three main questions (apart from the opening and ending questions) and the FGs lasted 45-100 minutes (see Table 1). The initial main questions were: What do you associate with climate change? Do you think that changing precipitation patterns or changes in temperature may change your production and, if so, how? If you have to respond to climate change, where do you get your information? The first two questions - the focus here - were intended to capture participants' immediate associations and further elaborations on chosen topics. The questions assumed that the answers would reflect national climate policy discussions 
and media coverage; therefore, they primarily concerned climate change mitigation and, secondarily, climate change adaptation. However, the discussions did not head in the direction I had initially anticipated, so I had to modify the questioning "on the fly." Participants turned out to be sceptical of climate change, did not believe it would significantly affect their agricultural production, and consequently saw little need for climate information. Following this turn in the discussions, I listened carefully, followed the line of thought, and asked for additional comments in order to understand the participants' views. The unpredictable course of the discussions and, hence, the changing interview guide illustrate the importance of an inductive research approach. As participants were allowed to determine the direction of their responses rather than reflecting researcher-defined themes, an opportunity for deeper insight emerged.

\section{Analysis of frames and framing processes}

I analysed the FG transcripts, focusing on the frames (i.e., central ideas) reoccurring throughout the material and on frame formation. I started the analytical process with a two-level thematic analysis, in which topics and themes are central (Markova, Linell, Grossen and Salazar Orvig, 2007). Firstly, I identified various topics in the FG transcriptions. Secondly, recurrent topics were grouped into "themes”. By recurrent I mean a topic that recurs in at least four groups. From the fairly non-theoretical list of the matters participants discussed, the next step included identifying frames - also called underlying assumptions (Marková et al., 2007) - which can be seen as abstract arguments we often unconsciously use in sense-making processes (Markova et al., 2007). I also paid attention to the frame-formation process by analysing the framing devices participants used to make sense of climate change. The analysis includes the farmers' use of keywords, metaphors, and prototypical examples (Entman, 1993; Nerlich and Koteyko, 2009). 


\section{Results}

This section comprises two sections reflecting the main findings of the study: 1) that farmers relate to and understand climate change through their own experience, and 2) that climate change is understood either as a natural process subject to little or no human influence or as anthropogenic.

\section{The importance of experiences to perceptions of climate change}

The participating farmers' experience of sometimes decades of agricultural production served as a starting point from which to discuss climate change. The farmers frequently used examples and comparisons (i.e., analogies and distinctions) based on their own experience to support or counter ideas or arguments. The following excerpt illustrates how experiences were elaborated on in the discussions by using such framing devices:

\section{Excerpt $1^{1}$ :}

Moderator What do you associate with climate change?

Will I think of (.) I've farmed since, well, what is it, 72 I started. So it has changed, the climate. That, I think of. The growing season is longer today than it was in 1972.

Ted And that's not a long-term perspective.

Will Nah, it's not long. I would say the growing season is typically 20 days longer today than it was in 72. That's my belief.

Ted In 30 years? (Will: yes)

Will On average per year. There have been setbacks but, after all, it has happened, a lot.

Sam But spring, the spring is late now, isn't it?

Will Yes, it’s late now. But it’s pretty normal this year, I think.

Sam But a little late, isn't it?

\footnotetext{
${ }^{1}$ Transcription conventions: (.) denotes a micro-paus, (2 s) denotes a timed paus, * * indicate laughter in the speaker's voice, (name $\mathrm{mm}$ ) denotes listener support, $\mathrm{XX}$ denotes speech that cannot be deciphered and [...] that a short sequence have been omitted (Linell, 1994).
} 
Will No.

Sam No, maybe not.

Morty But isn't it something that falls within normal variation? (X: yes) I mean, you've got 400year variations.

Will Looking at the 60s, it was very late. $(\mathrm{X}: \mathrm{mm})$ There were late springs and early autumns (X: much snow). Yes, a lot of snow every winter. Then it changed. Sure, we've had a few turns, a few setbacks, but if you look at those years, a considerable number of them were early. And autumn has been milder. (X m) And on our part, we have harvested all the way to December quite a few years, and that could never have been done before.

John $\quad$ Yes, you notice it very clearly in your production.

(FG 2)

As to what they associate climate changes with, participants started to discuss longer growing seasons; Will, in particular, claims that the climate has changed and that this is noticeable in one's daily chores. The excerpt illustrates how different ideas regarding the growing season length in different decades emerge, are adopted, and co-evolve to shape the meanings of climate change. As distinct from the 1970s, Will claims that today's growing season is longer than it used to be, reaffirming this claim by specifying that the growing season is 20 days longer. Will makes knowledge claims the other participants are hesitant to accept, as seen by the repeated attempts to argue against him. For example, Ted asks how many years were needed for such changes to be noticeable; Will, based on his own experience, answers with certainty. However, he opens up the discussion to alternative interpretations by suggesting that there have been occasions when the change has not been noticeable, though these events are seen as anomalies that the participant dismisses as exceptions. Thus, at the same time as he acknowledges other understandings, he downplays their importance. Yet another participant, Sam, poses a counter-question: "But spring, the spring is late now, isn't it?” This time Will only answers "No," supplying no arguments supporting the answer. Even so, Sam seems to change his mind, replying "No, maybe not." A new participant, Morty, enters the 
discussion, posing yet another question that challenges the claim of a changing climate by suggesting that variations should be understood as "normal." In response, Will once again reaffirms his argument based on experience over a 40-year period. The discussion ends with the formation of apparently shared knowledge of the subject, Will's arguments being prioritized because of their basis in experience and practical work.

This excerpt illustrates a recurrent form of argumentation in the material, and is interesting from several perspectives. First, it exemplifies how different ideas regarding climate change circulate, are shaped and upheld, and then disappear. It also exemplifies how participants jointly seek to understand climate change and, in interaction, construct their perceptions. In this example, it is the frame proposed by someone whose experience is deemed to best capture changes in weather and climate that is eventually shared by other participants.

In the above excerpt, experience was cited mainly to distinguish the length of growing seasons today from those in the 1970s, taking this as evidence of a change in the climate. However, other farmers in the group also used their experience to draw the opposite conclusion. In the following excerpt, one participant uses his experience of weather and agricultural practices since the 1950s to make claims about climate change and its existence:

\section{Excerpt 2:}

Colin And I have had personal experience of weather for 40 years. The first thing you do in the morning is look at the sky, so you have extensive experience of weather. As a farmer you remember some years. In the 1950s, you have a reference year when it was very, very hot at 30-35 degrees, huh. You remember the snowy winters in the 80s maybe, then green winters in the 1990s, and then one remembers the last two snowy winters. For 12-13 
years we had no snow at all. And then ask you the question - personally I do not feel that there has been climate change.

(FG 6)

The excerpt illustrates how experience is used to indicate, according to the participant, that there has been no climate change. Central to the argument is the analogy with variations occurring during different periods, such as the 1950s, 1980s, and 1990s, exemplified by summer high temperatures in the 1950s, snowy winters in the 1980s, but then green ones in the 1990s and snowy winters again in 2009 and 2010. The analogy refers to variations in the past and leads to the final statement: "I do not feel that there has been climate change.”

Excerpts one and two highlight the participants' elaboration of experience of weather patterns and their implications for agricultural production. Their experience is verbalized as comparisons between perceived variations in growing season length and as examples of temperatures and precipitation. The references to previous decades used as meaning-making resources - are not read or heard about, but based explicitly on experience. This illustrates the use of one's experience to attribute concrete meaning to climate change. As the excerpts suggest, similar observations can be used to draw very different conclusions, as arguments based on experience both supported and countered frames of human-induced climate change.

\section{Frame clashes: natural versus anthropogenic climate change}

In the focus groups, everyday experiences served as "evidence" from which to make claims regarding climate change. Different interpretations of experience then gave rise to two interpretations of what causes climate change: natural processes or human activities. These two frames were in dialogue with each other through argumentative 
cycles with either of the frames supported by certain keywords, metaphors, and prototypical examples (see Table 2).

Table 2. "Climate change” as framed by focus group participants

The table shows how different framing devices form the two frames of natural climate change and anthropogenic climate change during the discussions:

Keywords. While natural climate change was described in terms of recurring variations and cycles, human-induced climate change was understood as the word implies - as a change, as something new.

Time metaphors. While natural climate change was typically understood from a longterm time perspective in terms of slow change, human-induced climate change was understood from a shorter-term perspective and in terms of rapid change.

Prototypical examples. Examples served as a common framing device to support arguments. Some examples were cited repeatedly in the groups and stood as icons or prototypes of particular phenomena. As a general example, previous ice ages were frequently used as a prototype for natural climate change, along with the more contextspecific example that grapes had once been grown in Sweden. The importance of ice cover was also seen in the anthropogenic frame of climate change. Prototypical examples cited in discussions of human-induced climate change were the melting of glaciers and changed direction of the Gulf Stream. Like the time metaphors, these examples emphasize climate change as either gradual or catastrophic, revealing tensions between the two frames of climate change. 
Causes and responses. Causes were rarely discussed but, for those who believed in human-induced climate change, the consumption of fossil fuels was mentioned as a cause. In line with this framing, mitigation was thought of as a collective responsibility, though with "others” (e.g., the transport sector) being primarily responsible. Similar reasoning was found in the case of climate change adaptation. In framing climate change as anthropogenic, agricultural adaptation was seen as a collective responsibility, the research community being regarded as particularly responsible for developing new crops and for providing extension services to supply needed information (e.g., regarding new management practices). However, adaptation was mostly seen as adapting to political decisions and market trends, not to physical climate change as such. Those who framed climate change as natural commonly argued that the causes of climate change were impossible to determine; however, due to the long-term processes involved, human impact was perceived as insignificant. Consequently, activities to mitigate climate change were thought to be irrelevant and adaptation to be a fairly unproblematic matter that the agricultural sector had long dealt with.

Tensions and conflicts in discussions of climate change. Understandings of climate change as caused by natural processes versus human activities were implicitly and explicitly present, developed, and elaborated on throughout the discussions:

\section{Excerpt 3:}

Claire Do you believe in it? Climate change?

Maggie But what should one believe? (X: Huh?) But what should one believe? Is it something that is recurring, one wonders, if you think back on everything that has happened in nature before.

Catherine Yes, but there have been Ice Ages before (X: yes), so of course there have been climate changes (X: yes). Substantial ones (mm). It would be a bit unbelievable if there weren't. If suddenly there should stop being climate change and be (.) if it should stay exactly, those years when we live $(\mathrm{X}: \mathrm{mm})(\mathrm{X}: \mathrm{mm})$. Or what. It has changed. They think it has 
changed now - from what? (X: Yes) * laughs * Yeah, but what is it that is normal then? And what should that be based on? [...]

Claire $\quad$ You're right, Catherine, when I think about it (X: mm). Because I mean, when the ice sheet disappeared, it was just this kind of climate. It must have been like this since (Catherine: yes, it must have been a lot warmer then). It was warmer, yes. And you see. Life went on, and (X: mm) (X: yes).

Catherine Yes, it feels so natural somehow. [...]

(FG 3)

The excerpt illustrates how frames of natural versus anthropogenic climate change are central to participants' sense-making processes. The sequence starts after a long pause with a question from one participant to the others, asking whether they believe in climate change. The question indicates a critical or sceptical view of climate change. Maggie replies, “What should one believe?”, in turn highlighting the difficulty of being critical of a concept introduced by the policy and scientific communities, and seldom considered in the everyday language and practice of the participants. In turn three, Catherine enters the discussion and reiterates the idea of climate change as a natural phenomenon exemplified by ice ages in the past. Furthermore, Catherine states that it would be odd for such a natural long-standing process to stop. At the same time, she asks, “They think it has changed now - from what?”, indicating awareness of various possible interpretations of climate change espoused by "others.” The first participant again enters the conversation and reaffirms the proposed arguments for natural climate change. The sequence ends with "it feels so natural somehow." This excerpt illustrates a recurrent pattern in the data: the participants' joint sense-making process in which various arguments are suggested, elaborated on, and reformulated. Participants question one another, respond to one another, and use one another's reasoning to support their arguments. They jointly elaborate on an idea using various arguments and examples to 
support a thesis. What in the first place was an open question ended with shared knowledge expressed in the reply, i.e., that climate change is a natural process.

Although the idea of natural climate change permeated the discussions, a belief in human-induced climate change was expressed but was often met with counterarguments, such as:

- That may be in the short term. But in the long run, it is nevertheless natural variation. (FG 6)

- We cannot know the causes. (FG 4, 7)

- The intensity of the seasons has not changed. (FG 8)

- Extreme weather is nothing new. It comes and goes. (FG 7)

Natural climate change was often contrasted with anthropogenic climate change, the two frames treated as mutually exclusive. The participants never discussed how these two understandings could coexist, i.e., that climate change could be both natural and anthropogenic. Instead, these two frames became each other's opposites, one definition excluding the other.

\section{Discussion}

\section{Understanding rationales for action due to different frames}

From the analysis it can be concluded that different frames suggest different views of a phenomenon, and different ideas as to the causes, solutions, and necessary actions. In particular, this study emphasizes that there are many ways to understand and experience environmental problems such as climate change and that these may be at odds with natural scientific understandings and the behaviours proposed in response to them. 
As this study demonstrates, when climate change was framed as a natural process, with little or no human input, it was rarely recognized as a problem. If no problem exists, solutions are seen as spurious and motivation for action is absent. Mitigation was never discussed in the focus groups unless the moderator put it on the agenda. However, as climate change was found to represent a natural phenomenon that has always affected agricultural production, adaptation was seen as important. When participants framed climate change as a natural process, this implied that mitigation activities were deemed unnecessary - contrary to many proposals for Swedish agriculture from the Swedish Board of Agriculture (SBA, 2012), the news media (Olausson, 2009), and even farm magazines (Asplund et al., 2013). On a general level, there seemed to be a logical connection between how the farmers talked about climate change, their attention to certain elements, and their definitions of what is problematic coupled with suggestions for appropriate courses of action. This study indicates that when climate change is believed to be natural, support for mitigation and adaptation activities is low. Arbuckle et al. (2013) found a similar logical connection between diagnostic, prognostic, and motivational framings of climate change among American farmers. They found that belief in human-induced climate change and concern about impacts correlated with support for adaptive and mitigating actions (Arbuckle et al., 2013). Hence, different frames of climate change entail different assumptions as to the relevance of and need for mitigation and adaptation strategies. However, Snow and Benford (1988) suggest that there is more than a logical connection between a frame and its practical consequences for action, as agreement about causes and solutions to a particular problem do not automatically generate action, so rationales for action go beyond problem definitions and solutions to concern issues of motivation. Responses to climate change therefore may not necessarily be consistent with frames of climate change as natural versus anthropogenic but may well be consistent with other frames. To date, little research has 
examined motivational framings among various audiences', and further research is needed to deepen our understanding of the relation between problem identification, proposed solutions and rationales for action.

\section{Understanding why a certain frame is given precedence}

It has been suggested that climate change perceptions can be explained by demographic variables such as gender and voting intentions (EB, 2008; McCright and Dunlap, 2011) and by peoples' values, worldviews (Leiserowitz et al., 2013; Poortinga et al., 2011; Whitmarsh, 2011), and identity (Kahan et al., 2012). The importance of experience for environmental and climate perceptions has been recognized more recently (Akerlof et al., 2013; Myers et al., 2012; Ryghaug and Solli, 2012; Weber, 2010), simultaneously raising questions of an epistemological character: How are understandings of climate change acquired and, in particular, on what are understandings of climate change based?

Perceived experiences of climate change and the belief that climate change is happening have been found to be interdependent (Myers et al., 2012). Similarly, it has also been suggested that personal experiences of climate change heighten perceptions of climate change's local risks (Akerlof et al., 2013). The most frequently described personally experienced aspects of climate change are changes in seasons, weather (e.g., heavier rainfall and snowfall), lake levels, flooding, animal populations, and vegetation, according to Akerlof et al. (2013) and Ryghaug and Solli (2012), who have demonstrated that personal experience of, for example, weather changes, can be interpreted as evidence of climate change. The present study highlights that experience of the same event can be used as evidence for climate change being either a humaninduced or natural process. Similarly, Capstick and Pidgeon (2014) found two competing interpretations of a period of severe cold weather in the UK. They found that unusually cold weather could be interpreted as evidence either for or against the 
existence of climate change. As experience of the same event, for example, seasonal changes, can be used to frame climate change in different ways and support contrasting arguments, this highlights the many ways audiences can interpret climate change and, hence, the complexity of audience-specific understandings of climate change (for an overview of climate change frames, see Nisbet and Scheufele, 2009).

\section{Frame resonance and clashes in public understandings of climate change}

As previously suggested, Sweden may exemplify a country where there is frequent media reporting on climate change in both the broadcast and print media (Höijer, 2010; Olausson, 2009) and in specialized media targeting farmers (Anon 1, Anon 2). Both national news media and Swedish farm magazines have framed climate change as a scientific certainty (Anon 2; Olausson, 2009). While farm magazines also depicted climate change using frames of conflict between different production systems, national agricultural contexts, or sectors, frames of economic burden due to stricter climate policies (Anon 2), these frames were not as apparent in the focus group discussions. The farmers participating in the focus groups primarily framed climate change, in contrast to the certainty frame found in farm magazines, as natural, with little or no human component. The present empirical results emphasize that Swedish farmers' understandings of climate change do not always conform to those conveyed by either the specialized or mainstream media, suggesting resonance for the frame of climate change as human-induced but little resonance for the frame of climate change as natural. Due to the various reasons for prioritizing a certain frame of a phenomenon, for example, values, worldviews, identity, and, in particular, how these frames are constructed by experience, it is problematic to communicate climate science as comprising “accurate interpretations” (see, e.g., Myers et al., 2012, p. 346). Framing climate change as a risk that calls for collective action in terms of both climate change mitigation and adaptation stands in contrast to a frame in which mitigation is not an 
issue and adaptation is unproblematic. When scientific interpretations of the causes of and solutions to human-induced climate change do not conform to audience-specific frames of "natural climate change," frame conflict is likely to appear, potentially increasing the levels of distrust between partners in dialogue.

Moreover, as noted above, underlying the scientific understanding of human-induced climate change and lay knowledge of climate change as a natural process are questions of epistemology. While scientists learn via abstract and analytical reasoning, laypeople typically draw on associative thinking and personal experience when learning (Kahneman, 2011; Weber, 2010; Weiler et al., 2012). Consequently, climate change is not only framed in different ways, but the frames may be supported by different epistemologies, which could further complicate the communication of climate change, resulting in even greater frame clashes. However, knowledge of in-depth processes underlying climate perceptions may be of help to increase frame resonance in climate change communication processes. As communicators learn their audiences' interpretative frameworks and as a result consider how climate change communication can be tailored to specific audiences, the risk of frame clashes may decrease while possibilities for frame resonance increase - ultimately stimulating responses to climate change (Moser, 2012; Whitmarsh and Lorenzoni, 2010).

\section{Frames and audience segmentation}

Recent studies of public understanding of climate change highlight the importance of framing climate change in ways that resonate with the various interpretative frames of target groups (for an overview, see Wibeck, 2013). The present paper supports arguments emphasizing the existence of multiple publics, each with differing viewpoints, and problematizes the concept of "public opinion" as consensual and fixed 
(see, e.g., Barnett and Mahony, 2011; Michael, 2009; Mohr, Raman and Gibbs, 2013). For example, Swedish farmers could be categorized as Europeans and thereby likely to express frames of concern regarding climate change (EB, 2008, 2012) - frames that were not particularly present in the empirical material examined here. Moreover, Swedish farmers could also be categorized as Swedes, but they seem to differ somewhat from Swedes in general in their sense-making processes regarding climate change. While Wibeck (2014) demonstrates that the Swedish laypeople participating in focus groups associated climate change with severe consequences, citing examples of melting polar ice caps, endangered polar bears, floods, and droughts, Swedish farmers participating in focus groups paid little attention to such catastrophic climate change images. Although limited in their scope, these two studies illustrate quite different frames and framing processes among segments of the public in the same national context, and even within the same audience group.

Instead of segmenting the public according to demographic variables such as gender, age, or socio-economic background, or to their understandings, concerns, and emotional responses to an issue, this paper addressed public segmentation in terms of its relevance to a particular issue, i.e., climate change. The added value of doing so is the opportunity to identify culturally shared assumptions among the examined public - in this case, the relevance of agricultural practices and experiences when drawing conclusions about climate change. Similarly, in a study of Norwegian transportation sector managers, Ryghaug and Solli (2012) conclude that, although accepting the findings of climate science, the managers perceived climate change largely in terms of the damage to Norwegian roads caused by extreme weather events. Segmenting the public according to sector and professional identity has its strengths and weaknesses. It may reveal contextually important ways to frame climate change and its causes and solutions, as well as illuminate motives for action. Its weakness is perhaps the complexity that public 
segmentation entails in terms of endless processes of the identification, differentiation, and potential proliferation, or patterning, of publics (Michael, 2009).

\section{Conclusions}

This paper set out to study an audience-specific case of climate change communication by analysing how Swedish farmers perceive climate change, the "evidence" on which their perceptions of climate change are based, and the communicative tools that help shape their perceptions. I argue that a greater emphasis on sense-making processes would complement quantitative studies of climate change attitudes and perceptions. Furthermore, to fully understand different audiences' perceptions of climate change, I also deem it necessary not only to analyse climate change frames as static entities, but also to analyse how they are shaped and co-constructed in and through dialogical processes.

The focus group discussions with farmers illustrated how participants used their own experiences to draw conclusions about climate change, and how common framing devices, such as examples and comparisons, were used to draw conclusions, serving as evidence of either human-induced or "natural" climate change. The study also demonstrated that, when climate change is framed as a natural process subject to little or no human influence, mitigation responses are deemed unnecessary while adaptation responses are seen as fairly unproblematic. This research suggests that a greater focus is needed on how different target groups and segments of the public frame climate change, and on how such frames evolve, to better understand how climate change is ascribed quite different meanings.

\section{Acknowledgements}


To be added later to maintain the integrity of the review process.

Funding acknowledgement

\section{References}

Akerlof, K., Maibach, E. W., Fitzgerald, D., Cedeno, A. Y., \& Neuman, A. (2013). Do people "personally experience" global warming, and if so how, and does it matter? Global Environ Change 23(1):81-91.

Arbuckle, J., Stalker, L., Haigh, T., Hobbs, J., Knoot, T., Knutson, C., ... Widhalm, M. (2013). Climate change beliefs, concerns, and attitudes toward adaptation and mitigation among farmers in the Midwestern United States. Climatic Change 117(4): 943-950.

Asplund, T. (2011). Metaphors in climate discourse: An analysis of Swedish farm magazines. Journal of Science Communication, 10(04): 1-8

Asplund, T., Hjerpe, M., \& Wibeck, V. (2013). Framings and coverage of climate change in Swedish specialized farming magazines. Climatic Change, 117(1-2):197-209

Barnett, C., \& Mahony, N. (2011). Segmenting publics. National Coordinating Centre for Public Engagement (NCCPE) and the Economic and Social Research Council (ESRC). Retrieved from: http://www.esrc.ac.uk/_images/Segmenting-publics-fullreport_tcm8-18312.pdf 
BBC (2010). BBC climate change poll - February 2010. Retrieved from: http://news.bbc.co.uk/nol/shared/bsp/hi/pdfs/05_02_10climatechange.pdf.

Capstick , S.B. \& Pidgeon, N.F. (2014). Public perception of cold weather events as evidence for and against climate change. Climatic Change 122(4):695-708

Dewulf, A., Gray, B., Putnam, L., Lewicki, R., Aarts, N., Bouwen, R., \& Van Woerkum, C. (2009). Disentangling approaches to framing in conflict and negotiation research: A meta-paradigmatic perspective. Human Relations, 62(2):155-193

Entman, R.M. (1993). Framing: toward clarification of a fractured paradigm. Journal of Communication 43(4):51-58

Eurobarometer, (2008). Europeans' attitudes towards climate change. Special Eurobarometer 300, European Commission

Eurobarometer, (2012). Climate Change. Special Eurobarometer 372, European Commission

Gamson, W.A., \& Modigliani, A. (1994). The changing culture of affirmative action. In: Burstein, P. (ed) Equal employment opportunity: Labor market discrimination and public policy. New York: Aldine de Gruyter

Glauser, B.G., \& Strauss, A. (1967). The discovery of grounded theory: Strategies for qualitative research. Chicago: Aldine Publishing Company. 
Hulme, M. (2009). Why we disagree about climate change: understanding controversy, inaction and opportunity. Cambridge UK: Cambridge University Press

Höijer, B. (2010). Emotional anchoring and objectification in the media reporting on climate change. Public Understanding of Science 19(6):717-731

IPCC, (2007a). Impacts, Adaptation and Vulnerability. Contribution of Working Group II to the Fourth Assessment Report of the Intergovernmental Panel on Climate Change. Cambridge, UK; New York: Cambridge University Press.

IPCC, (2007b). Mitigation of Climate Change. Contribution of Working Group III to the Fourth Assessment Report of the Intergovernmental Panel on Climate Change. Cambridge, UK; New York: Cambridge University Press.

IPCC, (2013). Climate Change 2013. The Physical Science Basis. Working Group I Contribution to the Fifth Assessment Report of the Intergovernmental Panel on Climate Change. Summary for Policymakers. Retrieved from: http://www.climatechange2013.org/images/uploads/WGI_AR5_SPM_brochure.pdf

Kahan, D.M., Peters, E., Wittlin, M., Slovic, P., Ouellette, L.L., Braman, D., \& Mandel, G. (2012). The polarizing impact of science literacy and numeracy on perceived climate change risks. Nature Climate Change 2(10):732-735

Kahneman, D. (2011). Thinking, fast and slow. New York: Farrar, Straus and Giroux Kitzinger, J. (1994). The methodology of focus groups: the importance of interaction between research participants. Sociology of Health and Ilnessl 16(1):103-121 
Lakoff, G. (2010) Why it Matters How We Frame the Environment. Environmental Communication 4(1): 70-81

Leiserowitz, A., Maibach, E., Roser- Renouf, C., Feinberg, G., \& Howe, P. (2013). Global Warming’s Six Americas, September 2012. Yale University and George Mason University-Yale Project on Climate Change Communication, New Haven, CT

Leiserowitz, A., Maibach, E., Roser- Renouf, C., Feinberg, G., \& Rosenthal, S. (2014). Climate change in the American mind: April, 2014. Yale University and George Mason University-Yale Project on Climate Change Communication, New Haven, CT

Linell, P (1994) Transkription av tal och samtal teori och praktik. LinköpingUniversity: Tema Institute - Communication Studies.

Markova, I., Linell, P., Grossen, M., \& Salazar Orvig, A. (2007). Dialogue in focus groups: Exploring socially shared knowledge. London, UK: Equinox

McCright, A.M., \& Dunlap, R.E. (2011). Cool dudes: the denial of climate change among conservative white males in the United States. Global Environmental Change 21(4):1163-1172

Michael, M. (2009). Publics performing publics: of PiGs, PiPs and politics. Public Understanding of Science 18(5):617-631 
Mohr, A., Raman, S., \& Gibbs, B. (2013) Which Publics? When? Exploring the Policy Potential of Involving Different Publics in Dialogue Around Science and Technology. Didcot, UK: Sciencewise - ERC

Morgan, D. (1998). The focus group guidebook. Thousand Oaks, CA: SAGE

Moser, S.C. (2010). Communicating climate change: history, challenges, process and future directions. Wiley Interdisciplinary Reviews: Climate Change 1(1): 31-53

Myers, T.A., Maibach, E.W., Roser-Renouf, C., Akerlof, K., \& Leiserowitz, A.A. (2012). The relationship between personal experience and belief in the reality of global warming. Nature Climate Chang 3(4):343-347

Nerlich, B., \& Koteyko, N. (2009). Compounds, creativity and complexity in climate change communication: the case of “carbon indulgences”. Global Environmental Change 19:345-353

Nisbet, M.C. \& Scheufele, D.A. (2009) What's next for science communication? Promising directions and lingering distractions. American Journal of Botany 96(10):1767-1778

Olausson, U. (2009). Global warming-global responsibility? Media frames of collective action and scientific certainty. Public Understanding of Science 18(4):421436 
Pew Research Center (2013). GOP Deeply Divided Over Climate Change. Retrieved from: http://www.people-press.org/files/legacy-pdf/11-113\%20Global\%20Warming\%20Release.pdf

Poortinga, W., Spence, A., Whitmarsh, L., Capstick, S., \& Pidgeon, N. (2011). Uncertain climate: an investigation into public scepticism about anthropogenic climate change. Global Environmental Change 21(3):1015-1024

Ryghaug, M. \& Solli, J. (2012). The appropriation of the climate change problem among road managers: fighting in the trenches of the real world. Climatic Change 114(3-4):427-440

Ryghaug, M., Sørensen, K.H. \& Næss, R. (2011). Making sense of global warming: Norwegians appropriating knowledge of anthropogenic climate change. Public Understanding of Science 20(6): 778-795

SBA. (2007) One meter per hour - climate change impacts on Swedish agriculture. Report 2007:16. SBA, Jönköping, Sweden. [In Swedish]

SBA. (2012). A climate-friendly agriculture in 2050. Report 2012:35. SBA, Jönköping, Sweden [In Swedish]

Shuckburgh, E., Robison, R., \& Pidgeon, N. (2012). Climate science, the public and the news media: Summary findings of a survey and focus groups conducted in the UK in March 2011. Living With Environmental Change, Swindon, UK 
Smith, N. \& Joffe, H. (2013). How the public engages with global warming: A social representations approach. Public Understanding of Science 22(1):16-32

Snow, D.A. \& Benford, R.D. (1988). Ideology, frame resonance, and participant mobilization. International Social Movement Reserach 1(1):197-218

SOU, (2007). Sweden and climate change threats and potentials. SOU 2007:60, Stockholm [In Swedish]

Weber, E.U. (2010). What shapes perceptions of climate change? Wiley Interdisciplinary Reviews: Climate Change 1(3):332-342

Weiler, C.S., Keller, J.K., Olex, C. (2012). Personality type differences between Ph.D. climate researchers and the general public: implications for effective communication. Climatic Change 112(2):233-242

Whitmarsh, L. (2011). Scepticism and uncertainty about climate change: dimensions, determinants and change over time. Global Environmental Change 21(2):690-700

Whitmarsh, L. \& Lorenzoni, I. (2010). Perceptions, behavior and communication of climate change. Wiley Interdisciplinary Reviews: Climate Change 1(2):158-161

Wibeck, V., Abrandt Dahlgren, M. \& Öberg, G. (2007). Learning in focus groups: an analytical dimension for enhancing focus group research. Qualitative Research 7(2):249-267 
Wibeck, V. (2013). Enhancing learning, communication and public engagement about climate change - some lessons from recent literature. Environmental Education Research. Published online: 22 Jul 2013

Wibeck, V. (2014). Social representations of climate change in Swedish lay focus groups: local or distant, gradual or catastrophic? Public Understanding of Science 23(2): 204-219

Wolf, J. \& Moser, S.C. (2011). Individual understandings, perceptions, and engagement with climate change: Insights from in-depth studies across the world. Wiley Interdisciplinary Reviews: Climate Change 2(4): 547-569. 


\section{Tables}

Table 1. Group format

\begin{tabular}{|c|c|c|c|c|}
\hline Group & Group composition & Group size & Age & Discussion length \\
\hline 1 & $\begin{array}{l}\text { Combination of forest, crop, } \\
\text { and livestock production }\end{array}$ & $\begin{array}{l}1 \text { woman } \\
5 \text { men }\end{array}$ & $30-60$ & 77 min \\
\hline 2 & $\begin{array}{l}\text { Combination of forest, crop, } \\
\text { and livestock production }\end{array}$ & 6 men & $50-70$ & $74 \mathrm{~min}$ \\
\hline 3 & $\begin{array}{l}\text { Predominantly livestock } \\
\text { production }\end{array}$ & 6 women & $20-70$ & $46 \min$ \\
\hline 4 & Crop production & 3 men & $30-40$ & $103 \min$ \\
\hline 5 & $\begin{array}{l}\text { Combination of crop and } \\
\text { livestock production }\end{array}$ & $\begin{array}{l}3 \text { women } \\
4 \text { men }\end{array}$ & $20-40$ & $\sim 60 \mathrm{~min}$ \\
\hline 6 & Crop production & $\begin{array}{l}1 \text { woman } \\
6 \text { men }\end{array}$ & $30-70$ & $71 \mathrm{~min}$ \\
\hline 7 & $\begin{array}{l}\text { Combination of crop and } \\
\text { livestock production }\end{array}$ & 3 men & $30-80$ & $51 \mathrm{~min}$ \\
\hline 8 & $\begin{array}{l}\text { Combination of crop and } \\
\text { livestock production }\end{array}$ & 6 men & $20-30$ & $67 \mathrm{~min}$ \\
\hline
\end{tabular}


Table 2. "Climate change” as framed by focus group participants

\begin{tabular}{|c|c|c|}
\hline & Natural climate change & $\begin{array}{l}\text { Human-induced climate } \\
\text { change }\end{array}$ \\
\hline Keywords & $\begin{array}{l}\text { Cycles, variations, fluctuations, } \\
\text { shifts, alterations, and recurring } \\
\text { patterns }\end{array}$ & $\begin{array}{l}\text { Change, temperature increase, } \\
\text { human impacts, and something } \\
\text { new }\end{array}$ \\
\hline Time metaphors & $\begin{array}{l}\text { Characterized by long-term } \\
\text { perspectives - typically several } \\
\text { centuries, thousands of years, } \\
\text { "always" - and slow changes }\end{array}$ & $\begin{array}{l}\text { Characterized by shorter-term } \\
\text { perspectives, typically up to } 150 \\
\text { years, and rapid changes }\end{array}$ \\
\hline Causes & $\begin{array}{l}\text { Impossible to determine, human } \\
\text { impact is negligible }\end{array}$ & Use of fossil fuels \\
\hline $\begin{array}{l}\text { Prototypical } \\
\text { examples }\end{array}$ & $\begin{array}{l}\text { - ice ages as recurrent } \\
\text { phenomena/periods (general) } \\
\text { - grapes, wild or domesticated } \\
\text { (context-specific) }\end{array}$ & $\begin{array}{l}\text { - } \text { melting of glaciers } \\
\text { - changed direction of Gulf } \\
\text { Stream }\end{array}$ \\
\hline $\begin{array}{l}\text { Responses: } \\
\text { mitigation and } \\
\text { adaptation }\end{array}$ & $\begin{array}{l}\text { Mitigation not an issue and } \\
\text { adaptation unproblematic }\end{array}$ & $\begin{array}{l}\text { Mitigation and adaptation are } \\
\text { collective responsibilities; } \\
\text { "others” are primarily } \\
\text { responsible }\end{array}$ \\
\hline
\end{tabular}

